\title{
RESEARCH NOTE \\ Effect of genus and growth stage on the chemical and mineral composition of tropical grasses used to feed dairy cows
}

\author{
Gerardo L. Arzate-Vázquez ${ }^{1}$, Francisco A. Castrejón-Pineda ${ }^{1}$, René Rosiles- \\ Martínez ${ }^{1}$, Silvino Carrillo-Pita ${ }^{2}$; Sergio Angeles-Campos ${ }^{1}$, and Einar \\ Vargas-Bello-Pérez ${ }^{3}$ \\ ${ }^{1}$ Universidad Nacional Autónoma de México, Facultad de Medicina Veterinaria y Zootecnia, Departamento \\ de Nutrición Animal y Bioquímica. Ciudad Universitaria, 04510 Mexico. \\ ${ }^{2}$ Colegio Superior Agropecuario del Estado de Guerrero, Coordinación de Zootecnia. Av. Vicente Guerrero \\ Núm. 81 altos. Iguala, Guerrero. 6 y 9. 40000, Mexico. \\ ${ }^{3}$ Pontificia Universidad Católica de Chile, Facultad de Agronomía e Ingeniería Forestal, Departamento de \\ Ciencias Animales. Casilla 306, Santiago, Chile.
}

\begin{abstract}
G.L. Arzate-Vázquez, F.A. Castrejón-Pineda, R. Rosiles-Martínez, S. Carrillo-Pita, S. Angeles-Campos, and E. Vargas-Bello-Pérez. 2016. Effect of genus and growth stage on the chemical and mineral composition of tropical grasses used to feed dairy cows. Cien. Inv. Agr. 43(3): 476-485. In tropical production systems, dairy cows are rarely supplemented with minerals, which often lead to mineral imbalances. Grasses grown together in the same soil type and sampled at the same growth stage can vary widely in chemical and mineral composition; therefore, the objective of this study was to characterize the chemical and mineral composition of Urochloa spp., Megathyrsus spp., and Andropogon spp. at three different stages of growth in the same soil type. The content of dry matter (DM; g $\left.100 \mathrm{~g}^{-1}\right)$ was higher $(\mathrm{P} \leq 0.05)$ in Urochloa spp. than in Andropogon spp. and Megathyrsus spp. Hemicellulose, non-fiber carbohydrates and slowly degraded true protein contents were higher $(\mathrm{P} \leq 0.05)$ in Andropogon spp. than in Urochloa spp. and Megathyrsus spp. Ether extract, crude protein, rapidly degraded true protein and unavailable protein contents were not affected by genus, whereas ether extract, ash, neutral detergent fiber, non-fiber carbohydrates, rapidly degraded true protein and unavailable protein contents were not affected by growth stage. Compared with Urochloa spp. and Andropogon spp., Megathyrsus spp. had higher $(\mathrm{P} \leq 0.05)$ contents of $\mathrm{Na}$ and $\mathrm{Mg}$, intermediate $(\mathrm{P} \leq 0.05)$ contents of $\mathrm{Mn}$ and lower $(\mathrm{P} \leq 0.05)$ contents of $\mathrm{Zn}$. $\mathrm{P}, \mathrm{Na}$, and $\mathrm{K}$ contents were affected by growth stage. Compared with Megathyrsus spp. and Andropogon spp., Urochloa spp. was higher $(\mathrm{P} \leq 0.05)$ in $\mathrm{P}$ and $\mathrm{Na}$ contents. Results from this study may be useful in predicting the nutrient and mineral supply from forages in dairy production systems in tropical areas.
\end{abstract}

Key words: Cows, forage, nutritive value, ruminants, trace minerals.

\section{Introduction}

An adequate mineral supply guarantees proper function (structural, physiological, catalytic, and

Received May 26, 2016. Accepted November 14, 2016 Corresponding author: evargasb@uc.cl regulatory) in animals (Suttle, 2010). Grazing cattle must absorb 30 micronutrients, 7 macro-minerals, 9 trace minerals, 10 water-soluble vitamins and 4 fat-soluble vitamins to remain healthy and productive (Suttle, 2016). 
Tropical grasses are important components of ruminant diets in Mexico (Avilés-Nieto et al., 2013); however, in tropical production systems, animals are rarely supplemented with minerals, and this often leads to mineral imbalance. It has been shown that mineral imbalance affects the health status of dairy cattle; for example, it has been related to the pathogenesis of lameness (Zhao et al., 2015). Additionally, dairy cows consuming inadequate amounts of essential nutrients can suffer different health problems and often have impaired milk production and reproductive efficiency (NRC, 2001).

Grasses mature in response to internal (e.g., genetic) and external (e.g., soil and climate) factors, which can also provoke changes in mineral composition (Suttle, 2010). For example, $\mathrm{P}$ concentrations in forage plants decline with advancing maturity, whereas the decline is lower in legumes than in grasses (Coates et al., 1990). Concentrations of many minerals (e.g., $\mathrm{Co}, \mathrm{Cu}$, $\mathrm{Fe}, \mathrm{K}$, and $\mathrm{Mg}$ ) also decline, but rarely to the same extent as $\mathrm{P}$, which reflects an increase in the proportion of stem to leaf and old to new leaves ratios (with stems and old leaves having lower mineral concentrations than young leaves) (Minson, 1990). Grasses grown together on the same soil type and sampled at the same growth stage can vary widely in mineral composition (Suttle, 2010).

Since growth stage can affect mineral concentrations in grasses, as well as the lack of information regarding the mineral profile of tropical grasses in Mexico, the objective of this study was to characterize the chemical composition and mineral profile of Urochloa spp., Megathyrsus spp., and Andropogon spp. at three different stages of growth in the same soil type. Data from this study will provide information that could guide farmers in the choice of forage resources for improved dairy performance.

\section{Materials and methods}

\section{Cultivation conditions of grasses}

This study was conducted at the Centro de Estudios Profesionales del Colegio Superior Agropecuario (CSAEGRO) in Guerrero, Mexico (18 $15^{\prime} 52^{\prime \prime} \mathrm{N}$, $\left.99^{\circ} 38^{\prime} 52^{\prime \prime} \mathrm{W}\right)$. The climate is type AWo, which is the driest of the hot subhumid group, with a summer rainy season, an annual mean temperature of 25 ${ }^{\circ} \mathrm{C}$, and a total annual rainfall of up to $1135 \mathrm{~mm}$.

Experimental plots were $40.5 \mathrm{~m}$ wide and $6 \mathrm{~m}$ long, and the row spacing was $75 \mathrm{~cm}$ (54 rows per plot); the plots had been sown with Urochloa spp., Megathyrsus spp., and Andropogon spp. since 2009. Soil characteristics were as follows: colluvial and in situ soil, shallow $(0-25 \mathrm{~cm})$, sandy clay texture, moderate medium sub angular block structure, dark brown color, intermediate drainage, furrow erosion, and a $\mathrm{pH}$ of 6.6. Soil

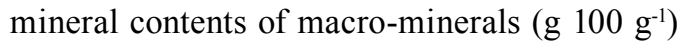
were 4.3 for $\mathrm{Ca}, 0.0008$ for $\mathrm{P}, 0.03$ for $\mathrm{Na}, 0.12$ for $\mathrm{K}$ and 0.42 for $\mathrm{Mg}$; the contents of microminerals $\left(\mathrm{mg} \mathrm{kg}^{-1}\right)$ were 3904 for $\mathrm{Fe}, 4$ for $\mathrm{Cu}, 235$ for $\mathrm{Mn}$ and 101 for $\mathrm{Zn}$. At the onset of the study, grasses from all plots were cut to homogenize growth. Forage samples were obtained at 4, 6 and 8 weeks of re-growth.

\section{Chemical composition}

Forage samples (leaves and stems) were clipped to a height of $15 \mathrm{~cm}$ and stored in paper bags at room temperature. Forage samples of $250 \mathrm{~g}$ were oven-dried at $60{ }^{\circ} \mathrm{C}$ for $24 \mathrm{~h}$, ground through a 1-mm screen using a Wiley mill (Arthur $\mathrm{H}$. Thomas, Philadelphia, PA), and then analyzed for dry matter (DM) (967.03), ash (923.03) ether extract (EE; 920.29), and crude protein (CP: $\mathrm{N} \times$ 6.25 ; 981.10) using standard procedures (AOAC, 1990). Neutral detergent fiber (NDF) and acid detergent fiber (ADF) were determined (Van 
Soest et al., 1991). Hemicellulose was calculated as NDF-ADF, and non-fiber carbohydrates (NSC) were calculated by the following formula: NSC $=100-(\mathrm{CP}+\mathrm{EE}+\mathrm{NDF}+\mathrm{ash})(\mathrm{DM}$ basis $)$. The $\mathrm{CP}$ from grasses was partitioned into five fractions (A, B1, B2, B3, and C) according to the Cornell Net Carbohydrate and Protein System. Another sample ( $0.5 \mathrm{~g}$ in duplicate) of forage material was incinerated in a muffle furnace at $500{ }^{\circ} \mathrm{C}$ for $16 \mathrm{~h}$ and stored at room temperature for mineral analysis.

\section{Mineral profile analysis}

The nutrient and mineral concentrations of forages were determined by wet ashing, using a digestion method. Forage samples of approximately $0.5 \mathrm{~g}$ were weighed into Teflon-lined digestion vessels to which $10 \mathrm{ml}$ of HCL was added and were allowed to digest for $25 \mathrm{~min}$ before being heated at $250{ }^{\circ} \mathrm{C}$ for $20 \mathrm{~min}$. After cooling, the samples were filtered through an ash-free filter paper and diluted in ion-exchanged distilled water to a final volume of $50 \mathrm{ml}$. The contents of $\mathrm{Ca}$, $\mathrm{Mg}, \mathrm{Cu}, \mathrm{Fe}, \mathrm{Mn}$, and $\mathrm{Zn}$ were detected by atomic absorption spectroscopy, whereas the contents of $\mathrm{Na}$ and $\mathrm{K}$ were analyzed by atomic emission spectrometry. Both analyses were performed using a 3110 Perkin-Elmer Atomic Absorption Spectrometer (The Perkin-Elmer Corporation, Norwalk, CT, USA) with standard conditions for each of the elements as described by the instrument manufacturer. P was measured by the molybdatevanadate method with UV spectrophotometry (965.17-1966, AOAC, 1995).

\section{Statistical analysis}

Statistical analysis was performed using the SAS Statistical Package (SAS Institute Inc., Cary, NC). The statistical design was a splitplot in time analysis, where the week of growth was the fixed effect. Data on the chemical and mineral compositions of Urochloa spp., Mega- thyrsus spp. and Andropogon spp. at 4, 6 and 8 weeks of growth were analyzed as repeated measurements using the General Lineal Models procedure of SAS. When significant treatment effects were detected, the means were separated using Tukey's test. Significance was declared at $\mathrm{P} \leq 0.05$.

\section{Results}

\section{Chemical composition}

The chemical composition of grasses varied according to genus and weeks of growth (Table 1). The contents of DM (g $\left.100 \mathrm{~g}^{-1}\right)$ were higher $(\mathrm{P} \leq 0.05)$ in Urochloa spp., than those found in Andropogon spp. and Megathyrsus spp. Hemicellulose and non-fiber carbohydrates contents were higher $(\mathrm{P} \leq 0.05)$ in Andropogon spp. than those observed in Urochloa spp. and Megathyrsus spp. The slowly degraded true protein contents were higher in Megathyrsus spp. than in Urochloa spp. and Andropogon spp.

Ether extract, crude protein, rapidly degraded true protein and unavailable protein contents were not affected by genus; ether extract, ash, NDF, non-fiber carbohydrates, rapidly degraded true protein and unavailable protein contents were not affected by growth stage. Dry matter, ADF and hemicellulose contents increased $(\mathrm{P} \leq 0.05)$ from week 4 to week 6 . Crude protein contents decreased $(\mathrm{P} \leq 0.05)$ from week 4 to week 8 . Slowly degraded true protein increased from week 4 to week 6 (Table 1).

\section{Mineral profile}

Compared with Urochloa spp. and Andropogon spp., Megathyrsus spp. had higher $(\mathrm{P} \leq 0.05)$ contents of $\mathrm{P}, \mathrm{Na}$, and $\mathrm{Mg}$, intermediate $(\mathrm{P} \leq 0.05)$ contents of $\mathrm{Mn}$ and lower $(\mathrm{P} \leq 0.05)$ contents of $\mathrm{Zn}$ (Table 2). Due to their low contents, $\mathrm{Cu}$ was not detected in either of the three grass genera. 
Contents of $\mathrm{P}, \mathrm{Na}$, and $\mathrm{K}\left(\mathrm{g} 100 \mathrm{~g}^{-1}\right)$, were affected by growth stage (Figure 1). Na contents increased from week 4 to week 6 in Megathyrsus spp. and Andropogon spp. and then decreased in week 8. Compared with Megathyrsus spp. and Andropogon spp., Urochloa spp. had higher $(\mathrm{P} \leq 0.05) \mathrm{Na}$ contents.

\section{Discussion}

\section{Chemical composition}

Forage is the most abundant and economical source of feed for cattle in tropical and subtropical grazing systems in Mexico (Juárez et al., 2005). In

Table 1. Chemical composition (g $100 \mathrm{~g}^{-1} \mathrm{DM}$ ) of Urochloa spp., Megathyrsus spp., and Andropogon spp. at 4, 6 and 8 weeks of growth.

\begin{tabular}{|c|c|c|c|c|c|}
\hline \multirow[b]{2}{*}{ Chemical analysis } & \multicolumn{3}{|c|}{ Genus } & \multirow[b]{2}{*}{$\mathrm{SED}^{3}$} & \multirow[b]{2}{*}{ P-value } \\
\hline & Andropogon & Urochloa & Megathyrsus & & \\
\hline Dry matter & $27.24 \mathrm{~b}$ & 29.49 a & $25.65 \mathrm{c}$ & 1.06 & $<0.001$ \\
\hline Ether extract & 5.42 & 5.86 & 5.53 & 0.271 & 0.204 \\
\hline Ash & $7.63 b$ & $10.90 \mathrm{a}$ & $11.39 \mathrm{a}$ & 0.302 & $<0.001$ \\
\hline Neutral detergent fiber & $72.39 \mathrm{a}$ & $70.15 b$ & $70.87 \mathrm{~b}$ & 0.866 & 0.046 \\
\hline Acid detergent fiber & $42.63 \mathrm{~b}$ & $42.38 \mathrm{~b}$ & $44.04 \mathrm{a}$ & 0.742 & 0.042 \\
\hline Hemicellulose ${ }^{1}$ & $29.76 \mathrm{a}$ & $27.77 \mathrm{~b}$ & $26.84 \mathrm{~b}$ & 0.700 & $<0.001$ \\
\hline Non-fiber carbohydrates ${ }^{2}$ & $12.86 \mathrm{a}$ & $10.64 \mathrm{~b}$ & $9.45 \mathrm{~b}$ & 0.834 & 0.001 \\
\hline Crude protein & 5.58 & 5.47 & 6.05 & 0.316 & 0.120 \\
\hline \multicolumn{6}{|l|}{ Protein fractions } \\
\hline A: non-protein $\mathrm{N}$ & $0.58 \mathrm{c}$ & $1.06 \mathrm{~b}$ & $1.15 \mathrm{a}$ & 0.146 & 0.002 \\
\hline $\mathrm{B} 1$ : rapidly degraded true protein & 0.51 & 0.49 & 0.52 & 0.029 & 0.641 \\
\hline B2: slowly degraded true protein & $0.70 \mathrm{c}$ & $0.92 \mathrm{~b}$ & $1.10 \mathrm{a}$ & 0.127 & 0.015 \\
\hline B3: by pass true protein & $1.87 \mathrm{a}$ & $1.03 \mathrm{c}$ & $1.30 \mathrm{a}$ & 0.168 & $<0.001$ \\
\hline \multirow[t]{3}{*}{ C: unavailable protein } & 2.02 & 1.82 & 1.99 & 0.109 & 0.752 \\
\hline & & Week & & & \\
\hline & $4 \mathrm{wk}$ & $6 \mathrm{wk}$ & $8 \mathrm{wk}$ & SED & P-value \\
\hline Dry matter & $24.89 \mathrm{~b}$ & $29.48 \mathrm{a}$ & $28.76 \mathrm{a}$ & 1.02 & $<0.001$ \\
\hline Ether extract & 5.44 & 5.55 & 5.97 & 0.261 & 0.108 \\
\hline Ash & 10.47 & 10.23 & 10.30 & 0.291 & 0.708 \\
\hline Neutral detergent fiber & 70.68 & 70.49 & 71.50 & 0.834 & 0.441 \\
\hline Acid detergent fiber & $41.60 \mathrm{~b}$ & $43.05 \mathrm{a}$ & $44.31 \mathrm{a}$ & 0.715 & 0.001 \\
\hline Hemicellulose & $29.08 \mathrm{a}$ & $27.44 \mathrm{~b}$ & $27.19 \mathrm{~b}$ & 0.674 & 0.012 \\
\hline Non-fiber carbohydrates & 10.59 & 11.28 & 10.34 & 0.804 & 0.485 \\
\hline Crude protein & $6.56 \mathrm{a}$ & $5.61 \mathrm{~b}$ & $4.88 \mathrm{c}$ & 0.305 & $<0.001$ \\
\hline \multicolumn{6}{|l|}{ Protein fractions } \\
\hline A: non-protein $\mathrm{N}$ & $1.04 \mathrm{a}$ & $1.22 \mathrm{a}$ & $0.63 \mathrm{~b}$ & 0.141 & $<0.001$ \\
\hline $\mathrm{B} 1$ : rapidly degraded true protein & 0.52 & 0.51 & 0.47 & 0.028 & 0.175 \\
\hline B2: slowly degraded true protein & $1.18 \mathrm{a}$ & $0.78 \mathrm{~b}$ & $0.83 \mathrm{~b}$ & 0.123 & 0.003 \\
\hline B3: by pass true protein & $1.78 \mathrm{a}$ & $1.16 \mathrm{~b}$ & $1.05 \mathrm{~b}$ & 0.162 & $<0.001$ \\
\hline C: unavailable protein & 1.96 & 2.01 & 1.95 & 0.105 & 0.843 \\
\hline
\end{tabular}

Means in the same row with different superscripts differ $(\mathrm{P} \leq 0.05) ;{ }^{1}$ Hemicellulose $=$ NDF-ADF; ${ }^{2}$ Non-fiber carbohydrates $=100-(\mathrm{CP}+\mathrm{EE}+\mathrm{NDF}+\mathrm{ash}) ;{ }^{3} \mathrm{SED}=$ Standard error of the difference. 
Table 2. Mineral contents of Urochloa spp., Megathyrsus spp., and Andropogon spp. at 4, 6 and 8 weeks of growth.

\begin{tabular}{|c|c|c|c|c|c|}
\hline \multirow[b]{2}{*}{ Minerals } & \multicolumn{3}{|c|}{ Genus } & \multirow[b]{2}{*}{$\mathrm{SED}^{1}$} & \multirow[b]{2}{*}{ P-value } \\
\hline & Urochloa & Megathyrsus & Andropogon & & \\
\hline $\mathrm{Ca}, \mathrm{g} 100 \mathrm{~g}^{-1} \mathrm{DM}$ & 0.37 & 0.32 & 0.43 & 0.03 & 0.138 \\
\hline $\mathrm{P}, \mathrm{g} 100 \mathrm{~g}^{-1} \mathrm{DM}$ & 0.08 & 0.13 & 0.10 & 0.01 & 0.059 \\
\hline $\mathrm{Na}, \mathrm{g} 100 \mathrm{~g}^{-1} \mathrm{DM}$ & $0.04 \mathrm{~b}$ & $0.10 \mathrm{a}$ & $0.04 \mathrm{~b}$ & 0.01 & 0.013 \\
\hline $\mathrm{K}, \mathrm{g} 100 \mathrm{~g}^{-1} \mathrm{DM}$ & 1.9 & 2.24 & 1.55 & 0.17 & 0.125 \\
\hline $\mathrm{Mg}, \mathrm{g} 100 \mathrm{~g}^{-1} \mathrm{DM}$ & $0.22 \mathrm{~b}$ & $0.26 \mathrm{a}$ & $0.20 \mathrm{c}$ & 0.01 & 0.041 \\
\hline $\mathrm{Fe}, \mathrm{mg} \mathrm{kg}^{-1} \mathrm{DM}$ & 232 & 199 & 207 & 19.9 & 0.545 \\
\hline $\mathrm{Mn}, \mathrm{mg} \mathrm{kg}^{-1} \mathrm{DM}$ & $42 \mathrm{a}$ & $25 \mathrm{~b}$ & $20 \mathrm{c}$ & 2.12 & 0.010 \\
\hline \multirow[t]{3}{*}{$\mathrm{Zn}, \mathrm{mg} \mathrm{kg}^{-1} \mathrm{DM}$} & $16 \mathrm{a}$ & $11 \mathrm{~b}$ & $15 \mathrm{a}$ & 0.42 & 0.006 \\
\hline & \multicolumn{3}{|c|}{ Week } & & \\
\hline & $4 \mathrm{wk}$ & $6 \mathrm{wk}$ & $8 \mathrm{wk}$ & SED & P-value \\
\hline $\mathrm{Ca}, \mathrm{g} 100 \mathrm{~g}^{-1} \mathrm{DM}$ & 0.37 & 0.37 & 0.37 & 0.02 & 0.937 \\
\hline $\mathrm{P}, \mathrm{g} 100 \mathrm{~g}^{-1} \mathrm{DM}$ & $0.13 \mathrm{a}$ & $0.10 \mathrm{~b}$ & $0.09 \mathrm{c}$ & 0.01 & 0.028 \\
\hline $\mathrm{Na}, \mathrm{g} 100 \mathrm{~g}^{-1} \mathrm{DM}$ & $0.06 \mathrm{~b}$ & $0.08 \mathrm{a}$ & $0.05 \mathrm{c}$ & 0.01 & 0.031 \\
\hline $\mathrm{K}, \mathrm{g} 100 \mathrm{~g}^{-1} \mathrm{DM}$ & $2.2 \mathrm{a}$ & $1.8 \mathrm{~b}$ & $1.69 \mathrm{c}$ & 0.12 & 0.003 \\
\hline $\mathrm{Mg}, \mathrm{g} 100 \mathrm{~g}^{-1} \mathrm{DM}$ & 0.23 & 0.22 & 0.21 & 0.01 & 0.388 \\
\hline $\mathrm{Fe}, \mathrm{mg} \mathrm{kg}^{-1} \mathrm{DM}$ & 246 & 227 & 164 & 29.1 & 0.201 \\
\hline $\mathrm{Mn}, \mathrm{mg} \mathrm{kg}^{-1} \mathrm{DM}$ & 30 & 29 & 28 & 2.21 & 0.710 \\
\hline $\mathrm{Zn}, \mathrm{mg} \mathrm{kg}^{-1} \mathrm{DM}$ & 14 & 14 & 14 & 0.75 & 0.947 \\
\hline
\end{tabular}

Means in the same row with different superscripts differ $(\mathrm{P} \leq 0.05),{ }^{1} \mathrm{SED}=$ Standard error of the difference.

terms of nutritional value, tropical grasses can be affected by their growth stage; therefore, maturity is considered the most important factor affecting the chemical composition and nutritional quality of forages (Ribeiro et al., 2014). The nutritional value of forages linearly declines with increasing physiological maturity (Santos et al., 2014). As observed in this study, the increase in DM content with increasing maturity was expected. The DM content of forages is important in calculating feed intake and improving milk production, but it is also important when farmers are interested in conserving this resource (i.e., silages). A DM content of $25 \%$ is recommended for minimizing effluent loss in silos and the preservation of nutrients in silages (Santos et al., 2014). In this study, grasses showed similar DM contents, showing their suitability for silage conservation.

Ruminants feeding on tropical forages obtain their energy mainly from the rumen microbial fermentation of structurally complex carbohydrates within plant cell walls (Van Soest et al., 1991). According to the NDF contents of the grasses evaluated in this study, forage intake would likely be reduced as NDF (approximately $71 \mathrm{~g} \mathrm{~kg}^{-1} \mathrm{DM}$ ) is negatively correlated with voluntary intake. As hemicellulose constitutes a portion of NDF, it was expected that NDF would also decrease from week 4 to week 8 , but this relationship was not observed in the present work. Juárez et al. (2005) noted that the major changes in the cell wall carbohydrates occurred before week 4 of re-growth.

In general, chemical compositions were different between genera and growth stage. NDF, ADF, and hemicellulose contents were similar to those previously reported for Adropogon gayanus (Olafadehan, 2013). Similarly, the NDF, ADF and CP contents found for Andropogon spp. were similar to those reported by Ribeiro et al. (2014) in Adropogon gayanus at 7 weeks of re-growth. The contents of DM, CP, NDF and ADF were 

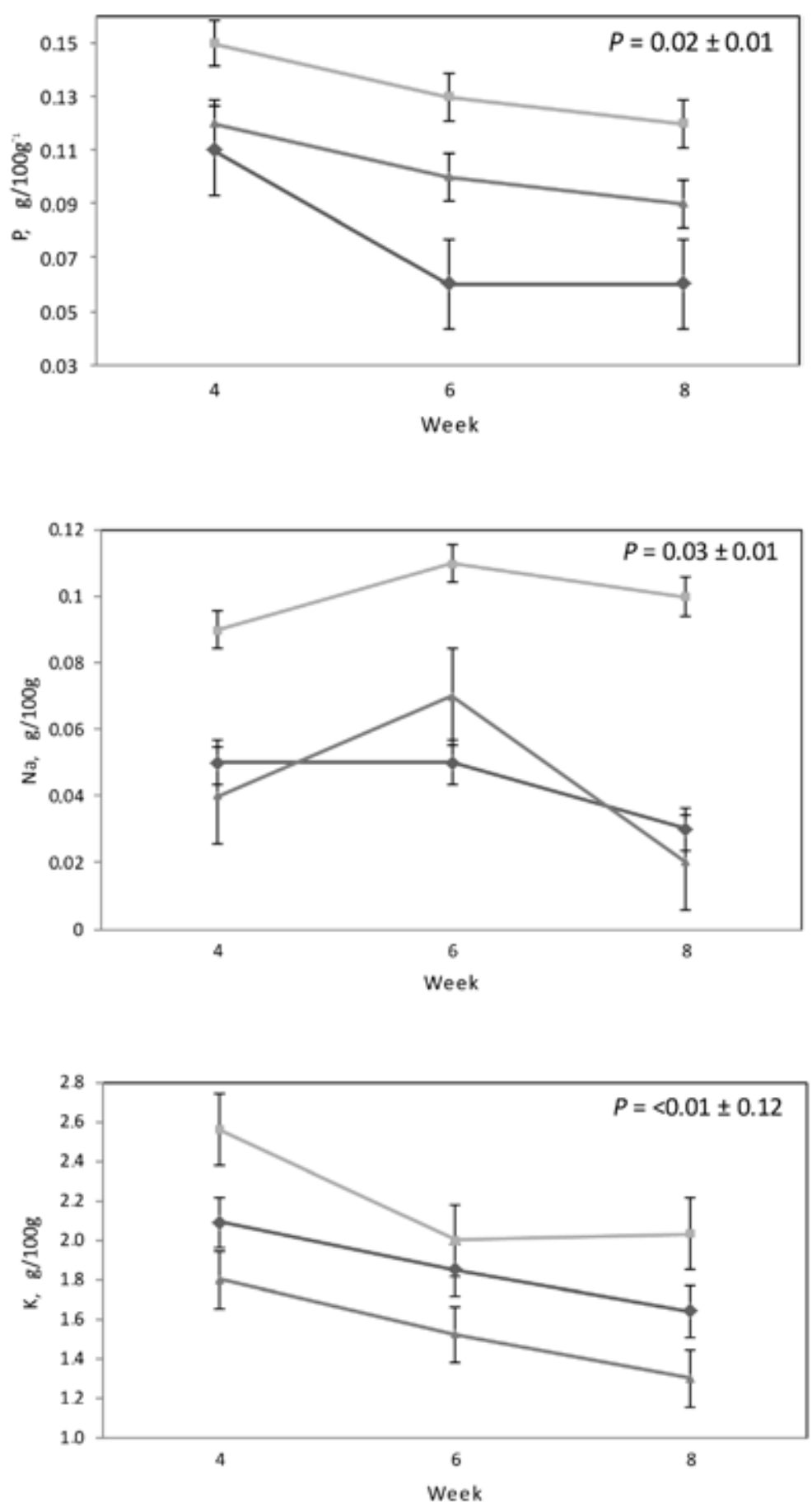

Figure 1. The contents of $\mathrm{P}, \mathrm{Na}$, and $\mathrm{K}$ in $(\diamond)$ Urochloa spp., (匹) Megathyrsus spp., and (A) Andropogon spp. at different growth stages. 
in agreement with those reported for Panicum maximum at 55 days of re-growth. Megathyrsus spp. contents of CP were similar to those reported by Aganga and Tshwenyane (2004), who found that the CP from this grass ranges from 5.5 to $20.5 \%$ of DM. In Urochloa spp., the contents of DM, NDF and EE were similar to those reported previously (de Oliveira et al., 2015) for Brachiaria brizantha harvested at $61 \mathrm{~d}$ of growth.

\section{Mineral profile}

Despite the expected high variability within species, this was not evaluated in this study; instead, we studied only mineral profile differences between genera in colluvial and in situ soil. However, variability among species in terms of mineral bioavailability must be considered, as some minerals vary considerably (Kambashi et al., 2014).

Under the conditions of this study, $\mathrm{Cu}(\leq 0.002$ absorbance units) was below the absorbance limit of detection of our equipment ( 0.003 absorbance units). Diets with as little as $0.4 \% \mathrm{~S}$ (i.e., 2 times the requirement) can have detrimental effects on cattle, ranging from secondary $\mathrm{Cu}$ and Se deficiencies to polioencephalomalacia (NRC, 2005).

Consumption of $\mathrm{Ca}$ is important during lactation because the amount of Ca per $\mathrm{kg}$ of milk produced varies slightly with the amount of protein in the milk, which also varies with breed; for example, the absorbed $\mathrm{Ca}$ required per $\mathrm{kg}$ of milk produced is $1.22 \mathrm{~g}$ in Holstein cows and $1.45 \mathrm{~g}$ in Jersey cows (NRC, 2001). In this study, grasses had between 0.32 to $0.43 \% \mathrm{Ca}$ content, which may not be enough for dairy cows in lactation, and supplementation would be highly recommended. For grazing cattle not fed with supplements, it is necessary to rely on both indirect and direct methods for providing minerals. The self-feeding of 'free-choice' mineral supplements is widely used for grazing cattle. Grazing animals pose a problem, and the provision of minerals and other supplements on a free-choice or free access basis is often the only practical method (Chládek and Zapletal, 2007).

$\mathrm{Na}$ was affected by growth stage, which is important to consider when designing strategies for rotational grazing systems because if cows are lactating, they will require mineral supplementation to avoid mineral imbalance and health problems. The Na, K, and P contents in Urochloa spp. and Megathyrsus spp. were similar to those reported by Kambashi et al. (2014) in tropical forages in the Democratic Republic of the Congo. The $\mathrm{Na}$ concentration in milk is $0.63 \mathrm{~g} \mathrm{~kg}^{-1}$, and for the NRC (2001), this is considered the requirement for absorbed Na for milk yield. During lactation, $\mathrm{K}$ in milk is fairly constant, even under different intakes, and the NRC (2001) requirement for absorbed $\mathrm{K}$ is $1.5 \mathrm{~kg}$ of milk produced. Based on the NRC (2001) recommendations for dairy cattle, a concentration within the range of 0.32 to $0.42 \%$ of $\mathrm{P}$ for the entire lactation period will be sufficient; however, this will depend on the milk production potential of the cows and the feed supplied.

In this study, the $\mathrm{Cu}$ content was not high enough to be detected. The Mn content was the highest in Andropogon spp., whereas the $\mathrm{Zn}$ content was higher in Urochloa spp. and Andropogon spp. These minerals are involved in numerous biological pathways during horn production, while $\mathrm{Mg}$ and $\mathrm{P}$ can improve the hardness and density of the hoof by speeding up the rate of formation and regeneration (Zhao et al., 2015).

Many feeds, especially forages, have extremely high concentrations of $\mathrm{Fe}$, but because of the low bioavailability of that $\mathrm{Fe}$, it is not an animal toxicity issue (NRC, 2005). According to the NRC (2001), a cow producing $25 \mathrm{~kg}_{\text {of milk d}}{ }^{-1}$ at 205 days of gestation and consuming $20 \mathrm{~kg} \mathrm{~d}^{-1} \mathrm{DM}$ requires $24 \mathrm{mg}$ of $\mathrm{Fe} \mathrm{kg}^{-1}$. The $\mathrm{Cu}$ requirement for dairy cows (NRC, 2001) varies according to days of gestation: $0.5 \mathrm{mg} \mathrm{day}^{-1}$ at 100 days of gestation, $1.5 \mathrm{mg} \mathrm{day}^{-1}$ if the gestation stage is 
between 100 and 225 days and $2.0 \mathrm{mg} \mathrm{day}^{-1}$ if the gestation stage is over 225 days.

In this study, micro-mineral (trace mineral) contents, such as Mn and Zn, were affected by grass genus, but Fe was not affected. This is important to consider since they are directly associated with reproductive performance and health problems such as mastitis. Trace minerals play an important role in dairy cow immune function, fertility, and growth (Machado et al., 2013).

The main conclusions are as follows. The contents of DM and ADF increased from week 4 to week 6 in Urochloa spp., Megathyrsus spp., and Andropogon spp., whereas CP decreased. Under the conditions of this study, $\mathrm{Ca}, \mathrm{Mg}, \mathrm{Fe}, \mathrm{Mn}$ and $\mathrm{Zn}$ contents were not affected by growth stage, whereas the $\mathrm{Na}$ content was reduced by growth stage in Urochloa spp., Megathyrsus spp., and Andropogon spp. Data from this study may be useful in calculating or predicting the intake of minerals in dairy production systems in tropical areas.

\section{Acknowledgments}

This study was supported by a grant from the Universidad Nacional Autónoma de México DGAPA-PAPIIT IN215310.

\section{Resumen}

G.L. Arzate-Vázquez, F.A. Castrejón-Pineda, R. Rosiles-Martínez, S. Carrillo-Pita, S. Angeles-Campos y E. Vargas-Bello-Pérez. 2016. Efecto del género y etapa de crecimiento sobre la composición química y mineral de pastos tropicales utilizados para alimentar vacas lecheras. Cien. Inv. Agr. 43(3): 476-485. En los sistemas de producción tropical, las vacas lecheras rara vez se suplementan con minerales y frecuentemente esto provoca un desequilibrio mineral. Los pastos que crecen en las mismas condiciones de suelo y que son muestreados en la misma etapa de crecimiento pueden variar en su composición química y mineral, por lo tanto el objetivo de este estudio es caracterizar la composición química y mineral de Urochloa spp., Megathyrsus spp., and Andropogon spp., en tres etapas distintas de crecimiento con las mismas condiciones de suelo. El contenido de materia seca $\left(\mathrm{g} 100 \mathrm{~g}^{-1}\right)$ fue mayor $(\mathrm{P} \leq 0.05)$ en Urochloa spp., que en Andropogon spp., y Megathyrsus spp. Los contenidos de hemicelulosa, carbohidratos no estructurales y proteína verdadera de degradación lenta, fueron mayores en $(\mathrm{P} \leq 0.05)$ Andropogon spp., que en Urochloa spp., y Megathyrsus spp. Los contenidos de extracto etéreo, proteína cruda, proteína verdadera de rápida degradación no fueron afectados por el género del pasto; mientras que el extracto etéreo, ceniza, fibra detergente neutra, contenido celular, carbohidratos no estructurales, proteína verdadera de rápida degradación y proteína no degradables tampoco fueron afectados por la etapa de crecimiento de los pastos. En comparación con Urochloa spp., y Andropogon spp., Megathyrsus spp., tuvo mayor ( $\mathrm{P} \leq 0.05)$ cantidad de $\mathrm{P}, \mathrm{Na}$ y $\mathrm{Mg}$, valores intermedios $(\mathrm{P} \leq 0.05)$ para $\mathrm{Mn}$ y valores menores $(\mathrm{P} \leq 0.05)$ para $\mathrm{Zn}$. P, Na y K fueron afectados por la etapa de crecimiento de los pastos. Comparado con Megathyrsus spp., y Andropogon spp., Urochloa spp., presentaron contenidos más altos $(\mathrm{P} \leq 0.05)$ de $\mathrm{P}$ y Na. Los contenidos de $\mathrm{K}$ fueron menores $(\mathrm{P} \leq 0.05)$ en Andropogon spp., que aquellos observados en Megathyrsus spp., y Urochloa spp. Los resultados de este estudio podrían ser utilizados para calcular o predecir el consumo de nutrientes y minerales de vacas lecheras en sistemas de pastoreo tropical.

Palabras clave: Forraje, minerales, rumiantes, vacas, valor nutricional. 


\section{References}

Aganga, A.A., and S. Tshwenyane. 2004. Potentials of guinea grass (Panicum maximum) as a forage crop in livestock production. Pakistan Journal of Nutrition 3:1-4.

AOAC. 1990. Official Methods of Analysis. 15th Edition. Association Official Analytical Chemists. Arlington, VA, USA.

AOAC. 1995. Official Methods of Analysis. 16th Edition. Association of Official Analytical Chemists. Arlington, VA, USA.

Avilés-Nieto, J.N., J.L. Valle-Cerdán, F. Castrejón-Pineda, S. Angeles-Campos, and E. Vargas-Bello-Pérez. 2013. Digestibility of Buffel grass (Cenchrus ciliaris)-based diets supplemented with four levels of Gliricidia sepium hay in hair sheep lambs. Tropical Animal Health and Production 45:1357-1362.

Chládek, G., and D. Zapletal. 2007. A free-choice intake of mineral blocks in beef cows during the grazing season and in winter. Livestock Science 106:41-46.

Coates, D.B., P.C. Kerridge, C.P. Miller, and W.H. Winter. 1990. Phosphorus and beef production in Australia. 7. The effect of phosphorus on the composition, yield and quality of legume based pasture and their relation to animal production. Tropical Grasslands 24:209-220.

de Oliveira, A.A., J.T. Zervoudakis, L.K. Hatamoto-Zervoudakis, L. Da Silva Cabral, R.P. Da Silva-Marques, J.F. Koscheck, D.M. Guedes de Carvalho, J.M. Benatti, and M.K. Alonso. 2015. Roasted soybean supplements for finishing beef cattle on Brachiaria brizantha pasture. Tropical Animal Health and Production 47:1233-1239.

Juárez, F.I., M. Montero, C. Serna, and E.G. Canudas. 2005. Evaluación nutricional de gramíneas forrajeras tropicales para bovinos en el centro del Estado de Veracruz. Avances en la Investigación Agrícola, Pecuaria, Forestal y Acuícola en el Trópico Mexicano. Libro Científico Número 2. INIFAP. Veracruz, México. p. 195-202.
Kambashi, B., P. Picron, C. Boudry, A. Théwis, H. Kiatoko, and J. Bindelle. 2014. Nutritive value of tropical forage plants fed to pigs in the Western provinces of the Democratic Republic of the Congo. Animal Feed Science and Technology 191:47-56.

Machado, V.S., M.L.S. Bicalho, R.V. Pereira, L.S. Caixeta, W.A. Knauer, G. Oikonomou, R.O. Gilbert, and R.C. Bicalho. 2013. Effect of an injectable trace mineral supplement containing selenium, copper, zinc, and manganese on the health and production of lactating Holstein cows. The Veterinary Journal 197:451-456.

Minson, D.J. 1990. Forages in Ruminant Nutrition. Academic Press, San Diego, California. p. 208-229.

NRC. 2001. Nutrient Requirements of Dairy Cattle. 7 th rev. ed. National Academy of Sciences. Washington, DC, USA.

NRC. 2005. Mineral Tolerance of Animals. 2nd rev. ed. National Academy of Sciences. Washington, DC, USA.

Olafadehan, O.A. 2013. Feeding value of Pterocarpus erinaceus for growing goats. Animal Feed Science and Technology 185:1-8.

Ribeiro, G.O. 2014. Production, nutritional quality and in vitro methane production from $A n$ dropogon gayanus grass harvested at different maturities and preserved as hay or silage. Asian Australasian Journal of Animal Sciences 27:330-341.

Santos, E.M., O.G. Pereira, R. Garcia, C.L.L.F. Ferreira, J.S. Oliveira, and T.C. Silva. 2014. Effect of regrowth interval and a microbial inoculant on the fermentation profile and dry matter recovery of guinea grass silages. Journal of Dairy Science 97:4423-4432.

Suttle, N.F. 2016. Ruminant Nutrition - Digestion and Absorption of Minerals and Vitamins. In: Reference Module in Food Science. Elsevier. Available online at: http:// www.sciencedirect.com/science/article/pii/ B9780081005965009641(Website accessed: October, 2016).

Suttle, N.F. 2010. Mineral Nutrition of Livestock. 4th Edition. CABI Publishing International. 
Van Soest, P.J., J.B. Robertson, and B.A. Lewis. 1991. Methods for dietary fiber, neutral detergent fiber, and nonstarch polysaccharides in relation to animal nutrition. Journal of Dairy Science 74:3583-3597.
Zhao, X.J., X.Y. Wang, J.H. Wang, Z.Y. Wang, L. Wang, and Z.H. Wang. 2015. Oxidative stress and imbalance of mineral metabolism contribute to lameness in dairy cows. Biological Trace Element Research 164:43-49. 